\title{
The future of organic farming - reflections on the new legislation
}

1. Regulations No $2018 / 848$ and $2020 / 464^{1}$ that will come in force on 1 January 2021 will introduce changes in many areas including the system of control and monitoring organic farming, the conversion of production to organic, or the imports of organic products. Organic farming belongs to dynamically developing agricultural sectors governed since 1992 by EU (earlier Community $)^{2}$ law. In legislation, organic production is recognised as "an overall system of farm management and food production that combines best environmental and climate action practices, a high level of biodiversity, the preservation of natural resources and the application of high animal welfare and high production standards in line with the demands of a growing number of consumers for products produced using natural means and processes." ${ }^{3}$

The subject matter referred to in the title of the article has not as yet been considered in the legal literature. Many publications concern the legal regu-

* Wydział Prawa i Administracji, Uniwersytet im. Adama Mickiewicza w Poznaniu.

1 Regulation (EU) 2018/848 of the European Parliament and of the Council of 30 May 2018 on organic production and labelling of organic products and repealing Council Regulation (EC) No 834/2007, OJ L 150/1 of 14 June 2018 (hereinafter referred to as Regulation No 2018/848); Commission Implementing Regulation (EU) 2020/464 of 26 March 2020 laying down detailed rules for the application of Regulation (EU) 2018/848 of the European Parliament and of the Council with regard to documents necessary for the retroactive recognition of periods for conversion, production of organic products and information to be provided by Member States, OJ L 98/2, 31.3.2020 (hereinafter referred to as Regulation No 2020/464).

2 See repealed Council Regulation (EEC) 2092/91 of 24 June 1991 on organic production of agricultural products and indications referring thereto on agricultural products and foodstuffs, OJ L 198, 22.07.1991, p. 1 (hereinafter referred to as Regulation No 2092/91).

${ }^{3}$ Recital 1 of the Preamble to Regulation No 2018/848. 
lations currently in force, which are reviewed in monographs, ${ }^{4}$ articles and other published papers. ${ }^{5}$ Neither have foreign publications studied legislation on organic farming from the perspective taken in this article. ${ }^{6}$

The article deals with issues that are relevant today mainly due to social-economic and cognitive reasons.

As far as the former is concerned, in recent years the organic farming sector in the European Union has been developing robustly not only in terms of the area used for organic farming, but also in terms of the number of farms and the total number of entities involved in ecological production. After Poland joined the European Union on 1 May 2004 there has been a significant increase in the organic farming area as well. According to reports of the Agricultural and Food Quality Inspectorate, in 2015 there were 7,182 organic farms in Poland occupying a total of 166,299.7 ha of arable land. ${ }^{7}$ In 2018, the total area of agricultural land on which organic production was carried out was already 484676.2 ha. ${ }^{8}$

The inclusion of organic farming in the support mechanisms of the Common Agricultural Policy gives farmers the opportunity to benefit from the support instruments provided for in EU regulations No 1305/2013 and $1307 / 2013 .{ }^{10}$ Organic farmers are privileged in some ways with regard to

${ }^{4}$ E.g. K. Leśkiewicz, System jakości produktów rolnictwa ekologicznego. Aspekty prawne, Poznań 2011; eadem, Ustawa o rolnictwie ekologicznym. Komentarz, Warszawa 2017; M. Korzycka, Żywność ekologiczna, in: M. Korzycka, P. Wojciechowski, System prawa żywnościowego, Warszawa 2017, pp. 351-381.

5 E.g. K. Leśkiewicz, Nowe spojrzenie na rolnictwo ekologiczne - aspekty prawne, "Przegląd Prawa Rolnego" 2014, No. 2, pp. 121-133.

${ }^{6}$ E.g. N. Lucifero, Il regolamento (UE) 2018/848 sulla produzione biologica. Principi e regole del nuovo regime nel sistema del diritto agroalimentare europeo, "Rivista di Diritto Agrario" 2018, No. 3, pp. 477-508.

7 The Main Inspectorate of Commercial Quality of Agricultural and Food Articles, Report on the state of organic farming in Poland in 2005-2006, Warsaw 2007, p. 11, https://ijhars.gov. pl/pliki/A-pliki-z-glownego-katalogu/ethernet/2012/BRE/BRE/Raport_eko.pdf [accessed on 30 January 2020].

${ }^{8}$ Report on the state of organic farming in Poland in 2017-2018, Warsaw 2019, p. 26, https://ijhars.gov.pl/pliki/A-pliki-z-glownego-katalogu/ethernet/2019/grudzien/SME/Raport\%20 ekologiczny_2017_2018_wersja_internet.pdf [accessed on 30 January 2020].

9 Regulation (EU) No 1305/2013 of the European Parliament and of the Council of 17 December 2013 on support for rural development by the European Agricultural Fund for Rural Development (EAFRD) and repealing Council Regulation (EC) No 1698/2005, OJ L 347, 20.12.2013, p. 487 (hereinafter referred to as Regulation No 1305/2013).

${ }_{10}$ Regulation (EU) No 1307/2013 of the European Parliament and of the Council of 17 December 2013 establishing rules for direct payments to farmers under support schemes within the framework of the common agricultural policy and repealing Council Regulation (EC) No 637/2008 and Council Regulation (EC) No 73/2009 OJ L 347, 20.12.2013, p. 608 (hereinafter 
certain payments (e.g. payments for greening) due to the fact that the environmental benefits of organic production are considered to be "evidenced." 11 There is therefore no doubt that the organic method is also important for achieving sustainable agriculture.

What is more, organic production is part of the EU's agricultural production quality schemes and Regulation No $1151 / 2012^{12}$ provides that organic products belong to the quality product group. Therefore, consumers have the right to expect these products to have specific characteristics resulting from the ecological methods of their production, and be subject to reliable certification.

As far as cognitive reasons are concerned, it should be remembered that in the period after Poland's accession to the European Union, the legal status of organic farming underwent a number of changes. In 2004, it was Regulation (EEC) No 2092/91 that was of key significance ${ }^{13}$ followed by the Act on organic farming of 2004. ${ }^{14}$ These legislative acts were subsequently replaced by others, including Regulation No 834/2007 15 and the Act on organic farming. ${ }^{16}$ The entry into force of the provisions of new Regulations (2018/848 and 2020/464) is still pending. The current legislation has been analysed in the literature with a view of determining whether it ascertains the proper protection of consumer interests and the quality of organic products. Some weaknesses of the legal solutions and the need to improve them have been identified. In particular, it was pointed out although the findings of the research suggested to the contrary, derogations from the requirements of organic production were made legally possible. ${ }^{17}$ Moreover, the competences of the certifying authorities in the control sys-

referred to as Regulation No 1307/2013); on support for organic farming under the common agricultural policy. For more see K. Leśkiewicz, Nowe spojrzenie na rolnictwo ekologiczne..., p. 121 et seq.

11 Ibidem, p. 124.

12 Regulation (EU) No 1151/2012 of the European Parliament and of the Council of 21 November 2012 on quality schemes for agricultural products and foodstuffs, OJ L 343, 14.12.2012, p. 1 (hereinafter referred to as Regulation No 1151/2012).

${ }_{13}$ Council Regulation (EEC) No 2092/91 of 24 June 1991 on organic production of agricultural products and indications referring thereto on agricultural products and foodstuffs, OJ L 198, 22.07.1991, p. 1 (hereinafter referred to as Regulation No 2092/91).

${ }_{14}$ Act of 20 April 2004 on organic farming, Journal of Laws, item 898 and 2007, items 541 and 1033, repealed by the Act on organic farming of 25 June 2009 (i.e. Journal of Laws 2019, item 1353).

${ }_{15}$ Council Regulation (EC) No 834/2007 of 28 June 2007 on organic production and labelling of organic products and repealing Regulation (EEC) No 2092/91, OJ L 189 of 20.07.2007, s. 1 (hereinafter Regulation No 834/2007).

16 The Act on organic farming of June 25, 2009 (i.e. Journal of Laws 2009, No. 153, item 259).

${ }^{17}$ K. Leśkiewicz, System jakości produktów..., p. 185. 
tem for organic farming were not sufficiently clearly defined..$^{18}$ Regulation No 2018/848 introduces new solutions and it is therefore justified to look at them against the background of the findings concerning Regulation No 834/2007 and related legislation. This is because producers as well as official control bodies must be adequately prepared for the application of the new regulations when they come into force.

For this reason, the purpose of the considerations in this article is to answer the question whether the new Regulation No 2018/848 serves to ensure the quality of organic products to a greater extent than Regulation No 834/2007 as regards exemptions from organic production requirements and the competences of supervising bodies.

2. The 2014 EU Action Plan for the future of organic production identifies certain challenges related to its application, and among them the need to ensure a steady increase in the supply and demand of organic products while maintaining consumer confidence and ensuring the credibility of the scheme and its long-term added value. ${ }^{19}$ The aim of the Action Plan is to promote the growth of the sector also in the light of the future regulatory changes, particularly by exploring new ways (medium and long-term) of addressing the challenges of supply and demand. In view of these objectives, the Action Plan for the period up to 2020 was to focus on three priority areas. The first one was to enhance the competitiveness of EU organic producers through: increasing knowledge of instruments available within the EU and related to organic production, enhancing synergies between them, addressing technical gaps in organic production through research, innovations and their dissemination, as well as wider availability of information on the organic production sector, including information on the market and trade. The second priority area was "consolidating and increasing consumer confidence in the European system as regards organic food and farming, as well as confidence in imported organic products and specifically in control measures." The third area of action identified in the Plan was strengthening the "external dimension of the EU organic production system." As the increase in the demand for organic products is clearly linked to consumer confidence and the guarantees provided by the system of control, it may be concluded that the Action Plan

18 Ibidem, p. 186.

${ }_{19}$ Communication from the Commission to the European Parliament, the Council, the European Economic and Social Committee and the Committee of the Regions Action Plan for the future of organic production in the European Union, Brussels, 24 March 2014. COM(2014) 179 final, https://ec.europa.eu/info/sites/info/files/food-farming-fisheries/farming/documents/ organic-action-plan_pl.pdf [accessed on 30 January 2020]. 
is a continuation of the approach of the past. It remains important to increase the competitiveness of producers and improve the quality assurance mechanisms for organic products, which is directly linked to consumer confidence.

3. The legislator emphasizes the application of Regulation No 2018/848 to products of agricultural origin, including products of aquaculture and apiculture, listed in Annex I to the TFEU, and to products derived from such products, where such products are or are intended to be produced, prepared, labelled, distributed, marketed or imported into or exported from the European Union as live or unprocessed agricultural products, including seeds and other plant propagating material, processed agricultural products intended for use as food or feed. ${ }^{20}$

This Regulation also applies to certain other products listed in Annex I to the Treaty, which are closely linked to agriculture and which are or are intended to be produced, prepared, labelled, distributed, marketed, imported into or exported from the European Union. Examples of those products include yeast used as food or feed, mate tea, sweetcorn, vine leaves, palm hearts, hop sprouts and other similar edible parts of plants and products made from them, sea salt and other salts used in food and feed, silkworm cocoon suitable for rolling, natural gums and resins. It is worth noting that the agricultural origin of the product in the case of organic products clearly distinguishes them from other food products. Even in the concept of food, the legislator does not require producers to respect the agricultural origin of food or its ingredients. ${ }^{21}$

The aim of the new regulation is continuation of the production of a wide range of high quality food and other agricultural and aquaculture products that meet consumer demand for goods produced using processes that do not endanger the environment, human health, plant health or animal health and welfare. ${ }^{22}$ In this respect, the new provisions continue the objectives set out in Regulation No 834/2007.

When examining the legal aspect of derogations from the requirements of organic farming, it should be recalled that in the provisions of Regulation No 834/2007, the possibility of such derogations was based on the principle of flexibility while the power to grant derogations lies with the EU Commission. These derogations should be kept to a minimum and only in the cases listed in article 22(2) of Regulation No 834/2007, e.g. when they are

${ }^{20}$ Article 1(1) of Regulation No 2018/848.

${ }^{21}$ Compare M. Korzycka, Zakres przedmiotowy prawa żywnościowego, in: M. Korzycka, P. Wojciechowski, System prawa ..., p. 175 et seq. and the literature cited therein.

${ }^{22}$ Article 5(d) of Regulation No 2018/848. 
necessary to ensure that organic production can be started or maintained in holdings which suffer from "climatic" or "geographical situation" or from "structural difficulties;" to ensure access to feed, seeds, vegetative propagating material, live animals and other farm inputs not available on the market as organic products.

The new provisions contained in the preamble to Regulation No 2018/848 indicate that derogations from the requirements for organic production should only be possible in the event of "catastrophic circumstances." In this respect, the Commission has also been conferred the appropriate powers to qualify certain circumstances as catastrophic and to indicate how Member States should proceed in such cases. ${ }^{23}$ This refers to the adoption of delegated legislative acts supplementing Regulation No $2018 / 848$ by laying down: the criteria for the eligibility of catastrophic circumstances resulting from an "adverse climatic event," an "animal disease," an "environmental incident," a "natural disaster" or a "disaster" under Regulation No 1305/2013, as well as any comparable situation; detailed rules including possible derogations on how Member States are to deal with such catastrophic circumstances; and detailed rules on monitoring and reporting in such cases. These criteria and regulations are subject to the principles of organic production established in Chapter II of Regulation No 2018/848. Linking the concepts in the regulation of organic farming with the regulations on rural development is a desirable measure from the point of view of consistency of legal solutions, which may have a positive impact on the achievement of the objectives of the regulation. Moreover, explicit limitations of derogations from the requirements of organic production seem to be an appropriate step towards a higher "production standard" and better quality assurance of organic products.

Thus, the possibility to derogate from the organic production requirements has been clarified and limited to the circumstances mentioned. However, there is a new possibility now for Member States to exempt operators from the obligation to hold a certificate if they sell non-prepackaged organic products other than feed directly to the final consumer, provided that such operators do not produce, prepare or store for purposes other than those relating to the point of sale or import such products from third countries or subcontract such operations to a third party, and provided that (1) such sales do not exceed $5000 \mathrm{~kg}$ per year, (2) do not represent an annual turnover of non-prepackeged organic products in excess of EUR 20000 , or (3) the potential cost of certification for the operator exceeds $2 \%$ of the total turnover

\footnotetext{
${ }^{23}$ Recital 60 of the Preamble and article 22 of Regulation No 2018/848.
} 
of non-prepackaged organic products sold by that operator. However, where Member States decide to make use of the exemption from the obligation in question, they may set stricter thresholds than those indicated above. ${ }^{24}$ This solution indicates a new possibility which admittedly corresponds to the promotion of direct sales, which however, at first sight, weakens the guarantees of quality of organic products.

Furthermore, what is new in the Regulation is the possibility of mutual internal controls carried out by producers in groups, provided that the criteria for the creation of a "group" as set out in article 36(1) of Regulation No 2018/848 are fulfilled. The group is required to establish a common system for the implementation of the products it produces and to develop an internal control system consisting of a documented set of activities and procedures.

On the other hand, as regards control and supervision, the objective of the new Regulation No 2018/848 is to ensure a harmonised approach across the European Union to the "measures" to be applied in the event of suspected non-compliance, for example due to the presence of unauthorised substances in organic products or in products in conversion. ${ }^{25}$ For these reasons, supervisory authorities or certifying authorities should carry out official enquiries in accordance with Regulation No $2017 / 625^{26}$ to verify compliance with the requirements for organic production. Where there is a suspicion of non-compliance due to the presence of unauthorised products or substances, the investigation should identify the sources and reasons for the presence of such products or substances.

Article 37 of Regulation No 2018/848 in Chapter VI entitled "Official controls and other official activities" indicates that the provisions of that Regulation are observed apart from those laid down in Regulation No 2017/625 and, unless otherwise provided for in articles 40(2), 29, 41(1),

${ }^{24}$ Article 35(8) of Regulation No 2018/848.

${ }^{25}$ Recital 69 of the Preamble to Regulation No 2018/848.

${ }^{26}$ Regulation (EU) 2017/625 of the European Parliament and of the Council of 15 March 2017. on official controls and other official operations performed to ensure the application of food and feed law, animal health and welfare, plant health and plant protection products and amending Regulations (EC) No 999/2001, (EC) No 396/2005, (EC) No 1069/2009, (EC) No 1107/2009, (EU) No 1151/2012, (EU) No 652/2014 of the European Parliament and of the Council, (EU) 2016/429 and (EU) 2016/2031, Council Regulations (EC) No 1/2005 and (EC) No 1099/2009 and Council Directives 98/58/EC, 1999/74/EC, 2007/43/EC, 2008/119/EC and 2008/120/EC, and repealing Regulations (EC) No 854/2004 and (EC) No 882/2004 of the European Parliament and of the Council, Council Directives 89/608/EEC, 89/662/EEC, 90/425/EEC, 91/496/EEC, 96/23/ EC, 96/93/EC and 97/78/EC, and Council Decision 92/438/EEC (the Official Controls Regulation), OJ L 95, of 7 April 2017, p. 1 (hereinafter referred to as Regulation No 2017/625). 
they apply to official controls and other official activities carried out with a view of checking the whole process at all stages of production, preparation and distribution. It may therefore be concluded that articles 38 to 43 of Regulation No 2018/848 lay down specific control requirements for organic farming in relation to the general system of official food control covered by Regulation No 2017/625.

The principle that remains is that official controls carried out in accordance with article 9 of Regulation No 2017/625 in order to verify compliance with Regulation No 2018/848 are carried out throughout the entire production process, at all stages including preparation and distribution. They are based on the examination of the likelihood of the appearance of non-compliance and with regard to the type, size and structure of the operators, the length of the period of organic production, subcontracting, and the like..$^{27}$ It is important to underline that the object of the control is the determination of whether there has been noncompliance with the provisions of both the Regulation and the implementing acts. ${ }^{28}$ In addition, it has been assumed that the absence of non-compliance means the integrity of organic products or products in conversion, understood to mean that the product does not exhibit any non-compliance which, at any stage of production, preparation and distribution, would affect the characteristics determining that the product is organic or in conversion; or which would be repetitive or intentional. ${ }^{29}$

It seems that in the scope indicated above the new regulation shows more precision in defining the tasks and competences of certification bodies. In particular, the legislator explicitly provides that control authorities or certification bodies should carry out official enquiries in accordance with Regulation No 2017/625 30 to verify compliance with the requirements for organic production. The activities of the certification bodies have been clearly

27 Article 38(2) of Regulation No 2018/848.

${ }^{28}$ Article 3(57) of Regulation No 2018/848.

${ }^{29}$ Article 3(74) of Regulation No 2018/848.

${ }^{30}$ Regulation (EU) 2017/625 of the European Parliament and of the Council of 15 March 2017 on official controls and other official operations performed to ensure the application of food and feed law, animal health and welfare, plant health and plant protection products and amending Regulations (EC) No 999/2001, (EC) No 396/2005, (EC) No 1069/2009, (EC) No 1107/2009, (EU) No 1151/2012, (EU) No 652/2014 of the European Parliament and of the Council, (EU) 2016/429 and (EU) 2016/2031, Council Regulations (EC) No 1/2005 and (EC) No 1099/2009 and Council Directives 98/58/EC, 1999/74/EC, 2007/43/EC, 2008/119/EC and 2008/120/EC, and repealing Regulations (EC) No 854/2004 and (EC) No 882/2004 of the European Parliament and of the Council, Council Directives 89/608/EEC, 89/662/EEC, 90/425/EEC, 91/496/EEC, 96/23/EC, 96/93/EC and 97/78/EC, and Council Decision 92/438/EEC (the Official Controls Regulation), OJ L 324, 30.12.2004, p. 1; OJ L 95, 7.04.2017, p. 1 (hereinafter referred to as Regulation No 2017/625). 
assigned an official character. First of all, Regulation No 2018/848 emphasises the importance of ensuring compliance of organic production with the applicable provisions.

The solution that has been adopted is that the competent authorities may delegate certain official control tasks and certain tasks related to other official activities to certification bodies only if, in addition to the conditions contained in Chapter III of Regulation (EU) No 2017/625, the following conditions are met. In other words, the delegation of tasks includes a detailed description of the official control tasks and tasks related to other official activities delegated, including reporting obligations and other specific obligations, and a description of the conditions under which the certification body may carry them out. In particular, the certification body must comply with the requirement to submit to the competent authorities for prior approval:

- its risk assessment procedure stating specifically the basis for the intensity and frequency of the review of operators' and groups of operators' compliance, which must be developed in accordance with Regulation No 2017/625 and article 38 of Regulation No 2018/848, and followed during official controls of operators and groups of operators;

- standard control procedures containing a detailed description of the control measures that the certification body undertakes to impose on operators and groups of operators;

- a list of measures consistent with the common catalogue to be applied in respect of operators and groups of operators where non-compliance is suspected or found;

- the agreed ways for effective monitoring and reporting of official control tasks and tasks relating to other official activities carried out in respect of operators and groups of operators and for reporting on those tasks.

In addition, competent authorities must ensure procedures for the supervision of certification bodies, including verification of the effectiveness, independence and objectivity of the way in which they carry out their tasks, in particular as regards the intensity and frequency of the verification of compliance. ${ }^{31}$

The standard for the delegation of certain official control tasks and certain tasks related to other official activities for the verification of compliance is the most recently published version of the international harmonised standard "General requirements for bodies operating product certification systems." ${ }^{32}$ Among the powers that Regulation No 2018/848 has conferred on control

${ }^{31}$ Article 40(1) of Regulation No 2018/848.

32 Article 40(2) of Regulation No 2018/848. 
authorities or certification bodies is, for example, the obligation to carry out an investigation and to temporarily prohibit the marketing of products as organic. ${ }^{33}$

4. To sum up, several final conclusions may be drawn from the considerations carried out above. The provisions of Regulation No 2018/848 introduce completely new solutions. On the one hand, the scope of possible derogations from the organic production requirements has been limited to the emergence of catastrophic circumstances and linked to the rural development legislation. This suggests that the rigour of the organic production requirements in this respect has been tightened. Such a development of the legislation helps to build consumer confidence in organic products in the future.

On the other hand, the new regulation allows derogations from the certification requirement for operators who sell non-prepackaged organic products other than feed to the final consumer directly. This applies to products sold under the conditions indicated in the legislation for annual sales volumes or annual turnover values, not originating from third countries, which, even if justified in terms of promoting direct sales, may raise doubts as to whether the quality of products will be properly ensured. Furthermore, as regards the control system, it has been made possible for private internal control systems to operate in producer groups indicated in the new legislation. However, if the supervision of the systems is not adequately ensured, this may not serve the purpose of providing adequate guarantees of product quality, either.

As regards the powers of the certification bodies, the terminology used to define the subject of control and certification has been further clarified and there is also a clear indication of the criteria that have to be met in order for the certification bodies to be delegated tasks in the organic farming control system, which includes powers of competence such as the issuance of a temporary ban on the marketing of products. In any case, additional conditions have to be met, and in particular an explicit basis for administrative decisions by these bodies must be laid down in national legislation. There is no doubt that these bodies carry out tasks of a public nature.

In the light of the findings, it may be stated that, at the end of the day, the practice of applying the rules will provide an answer to the question of whether the new regulation serves to ensure the quality of organic products to a greater extent and to the effect that it strengthens consumer confidence. As regards the powers of certification bodies in the control and certification system, this issue requires more specific solutions that need to be introduced in the legislation of European Union Member States.

${ }^{33}$ Article 41(1b) of Regulation No 2018/848. 


\title{
THE FUTURE OF ORGANIC FARMING - REFLECTIONS ON THE NEW LEGISLATION
}

\begin{abstract}
Summary
The purpose of the considerations is, taking into account the scope of derogations from the requirements of organic production and the competence of certifying authorities, to answer the question whether in comparison to Regulation No 834/2007, new Regulation No 2018/848 serves to ensure the quality of organic products. The authoress takes a positive view on limiting possible exemptions from the requirements of organic production to natural disasters and linking them to the provisions on rural development. At the same time she expresses a negative opinion on the possibility of seeking exemption from the requirement to obtain certificates. In relation to the competences of the certifying authorities, the new Regulation retains a greater terminological precision in determining the subject of control and certification and defines more precisely the criteria for delegating tasks in the organic farming control system to institutions. This issue, however, needs to be detailed in the legislations of European Union Member States.
\end{abstract}

\section{IL FUTURO DELL'AGRICOLTURA BIOLOGICA: RIFLESSIONI BASATE SULLA NUOVA REGOLAZIONE GIURIDICA}

\author{
Riassunto
}

L'articolo si propone di rispondere alla domanda se, rispetto al regolamento n. 834/2007 e visti le esenzioni dai requisiti di produzione biologica nonché le competenze degli organismi di certificazione, il nuovo regolamento n. 2018/848 riesca a garantire la qualità dei prodotti provenienti da agricoltura biologica. L'Autrice valuta positivamente il fatto di aver introdotto limiti, riportati a circostanze catastrofiche, nell'accordare possibili eccezioni dall'adempiere ai requisiti di produzione biologica e di averli ricondotti alle disposizioni in materia di sviluppo rurale; negativamente, invece, l'ammissione di eccezioni dall'obbligo di ottenere certificati. Per quanto riguarda le competenze degli organismi di certificazione, la nuova regolazione presenta una maggiore precisione terminologica nel definire l'oggetto di controllo e di certificazione, e definisce con più precisione i criteri per la delega dei compiti agli organismi evocati nell'ambito del sistema di controllo dell'agricoltura biologica. Tuttavia la questione in oggetto richiede tuttora altre precisazioni da inserire nella legislazione degli Stati membri dell'Unione europea. 